\title{
Dispersal and survival of juveniles of dominant tree species in a tropical rain forest of West Sumatra
}

\author{
Erizal MuKhTAR ${ }^{1}$ and Fumito KoIKE ${ }^{2}$ \\ ${ }^{1}$ Department of Biology, Faculty of Mathematics and Natural Sciences, Andalas University, Padang 25163, West Sumatra, Indonesia \\ ${ }^{2}$ Graduate School of Environment and Information Sciences, Yokohama National University, 79-7 Tokiwadai, Hodogaya-ku, Yokohama \\ 240-8501, Japan
}

\begin{abstract}
Adult trees of a given species distribute sparsely in tropical rain forests due to high tree species diversity, and dispersal and survival of juveniles are important processes to form such a pattern. Dispersal and juvenile survival of seven tree species were studied over 13 years in a 1-ha plot of tropical rain forest in Ulu Gadut, West Sumatra, Indonesia. All individuals of juveniles were marked and examined in 1989, 1998 and 2002. Estimation of dispersal kernel was successful for Calophyllum soulattri having the highest juvenile density among 7 species. Although dispersal kernel was significant in Gonystylus forbesii and Mastixia trichotoma, actual juvenile density was lower than expected in some subplots having high expected sapling density. Significant reduction of the sapling survival rate by neighboring conspecific saplings was detected in Calophyllum soulattri and Hopea dryobalonoides, and that by conspecific trees was detected in Swintonia schwenkii and Cleistanthus glandulosus. The negative effect of conspecific plants on juvenile survival was a more important factor than topography, and may be common in tropical rain forest trees. Aggregated distribution of saplings around mother trees might be formed just after seed dispersal; however, such patterns might be obscured by high mortality around mother trees, and relatively uniform tree distribution may be formed. Since regeneration is a rare phenomenon due to gregarious reproduction, we might be able to observe only limited stages of these processes simultaneously.
\end{abstract}

Key Words: dispersal, survival, juveniles, tropical forest

\section{INTRODUCTION}

Adult trees of a given species distribute sparsely in tropical rain forests, reflecting high tree species diversity, and dispersal and survival of tree juveniles are important processes in biodiversity conservation (Trakhtenbrot et al. 2005). Various studies on seed dispersal have been reported applying recent parameterization techniques (Ribbens et al. 1994; Clark et al. 1999). Most attention has been paid to measure the distribution of dispersal distance (Nathan et al. 2003; Nathan \& Casagrand, 2004; Greene et al. 2004; Komuro \& Koike 2005; Skarpaas et al. 2005; Ohtani \& Koike, 2005).

Spatial variation in juvenile survival is another important factor determining distribution patterns of adult trees. Ground surface relief may affect the survival of juveniles through water condition and resource availability (Russo et al. 2005). Aggregated distribution of juveniles and the existence of large trees may prohibit the survival of conspecific juveniles (Mukhtar et al. 1998; Clark et al. 1999).

Several ecological studies in a foothill rain forest in Ulu Gadut, West Sumatra have been carried out since 1980, including growth and death of trees (Kohyama et al. 1989), spatial distribution pattern of representative tree species (Kohyama et al. 1994), dynamics of above ground big woody organs (Yoneda et al. 1990), horizontal variance of stand structure (Yoneda et al. 1994), impact of dry weather on the stand dynamics (Yoneda et al. 2006), canopy structure (Koike \& Syahbuddin, 1993), and soil quality characterization in relation to tree species diversity (Kubota et al. 2000). Although the dispersal pattern of Swintonia schwenkii seeds (Suzuki \& Kohyama, 1991) and survival of Calophyllum soulattri (Mukhtar et al. 1992, 1998) were studied, dispersal and survival of other species have not yet been studied, and general patterns in tree species there are still unknown.

In this study, we investigated whether dispersal 
limitation could be detected in common tree species, and evaluated effects of neighboring conspecific plants and topography on the survival of juveniles of these species.

\section{METHODS}

\section{Study site}

This study was carried out at a 1.00 ha permanent plot, named Pinang-pinang plot in a foothill forest of Mt. Gadut (Lat. $0^{\circ} 55^{\prime} \mathrm{S}$, Long. $100^{\circ} 30^{\prime} \mathrm{E}$, elevation ranged from 575 $\mathrm{m}$ to $605 \mathrm{~m}), 18 \mathrm{~km}$ east from Padang, West Sumatra, Indonesia. This plot is covered primarily by mature trees occurring in patches with sporadic gap and regrowth patches. Detailed description of the vegetation can be found in the previous papers (Kohyama et al. 1989; Yoneda et al. 1990).

The plot was set up in 1981 consisted of 115 subplots of approximately equivalent areas. In this research, topographic environments (slope inclination, laplacian representing concavity, and logarithm of specific catchment area representing wetness) were calculated using a free GIS (Koike, 2005) from $1 \mathrm{~m}$ mesh DEM based on a contour map drawn by Ogino et al. (1984). The average value for each subplot was used for analysis.

\section{Studied species}

We chose seven tree species having many saplings. Saplings of these species are common and dominant on the forest floor. These include emergent tree species (Swintonia schwenkii T \& B), canopy tree species (Calophyllum soulattri Burm, Hopea dryobalanoides Miq.), and sub-canopy tree species (Cleistanthus glandulosus Jabl., Mastixia trichotoma B1., Grewia florida Miq. and Gonystylus forbesii Gilg). The characteristics of the selected seven tree species are shown in Table 1.

\section{Field survey for juveniles and trees}

The position of target tree species $(\mathrm{DBH}>9 \mathrm{~cm})$ was mapped in 1981, and diameter measurement data from 1989 and 1996 were used for analysis. The saplings (0-100 $\mathrm{cm}$ in height) and young trees (101-1000 cm in height) of the seven species were marked in September 1989, and re-examined in September 1998 and September 2002. Positions and plant height were measured in these surveys.

\section{Dispersal kernel}

The dispersal kernel is a mathematical function that represents the expected density of juveniles from one mother tree. Various dispersal kernel calculations have been proposed (Clark et al. 1999; Nathan et al. 2003; Nathan \& Casagrand, 2004; Skarpass, 2005; Ohtani $\&$ Koike, 2005). We employed the dispersal kernel, assuming the exponential decrease of sapling density with the distance from a mother tree. Since we could not obtain the minimum tree size for reproduction, the number of saplings produced by a mother tree was assumed to be proportional to the basal area of each mother tree. The dispersal kernel we employed is thus :

$$
D_{j}=\sum_{i=1}^{n} a B_{i} e^{r x_{i j}}
$$

where $D_{j}$ is the density of saplings $\left(\mathrm{m}^{-2}\right)$ in the $j$-th subplot, $B_{i}$ is the basal area $\left(\mathrm{m}^{2}\right)$ of the $i$-th mother tree, $x_{i j}$ is the distance from the $i$-th mother tree to the center of $j$-th subplot, and $n$ is the number of mother trees considered. Regression coefficient $a$ represents the sapling density just under the mother tree of $1 \mathrm{~m}^{2}$ in basal area. Regression coefficient $r$ is always negative, and a large absolute value of $r$ represents a steep decline of sapling density in relation to the distance from the mother tree. Since we considered all sizes of trees as potential mother trees, much effort would have been required to obtain the distribution of all mother trees outside of the plot. We however considered mother trees only in the plot as target tree species are abundant in the plot, and the plot located on the ridge top is somewhat of an "island" of

Table 1. Tree species studied. Dispersal agents were estimated from propagule morphology and personal observations.

\begin{tabular}{llccc}
\hline \multicolumn{1}{c}{ Species } & \multicolumn{1}{c}{ Family } & Maximum DBH & Dispersal agents & Latest mass reproduction before 1989 \\
\hline Calophyllum soulattri. & Guttiferae & 65.4 & Bats & 1981 \\
Cleistanthus glandulosus & Euphorbiaceae & 29.1 & Birds & Not known \\
Gonystylus forbesii & Thymelaceae & 43.7 & Animal? & Not known \\
Grewia florida & Tiliaceae & 29.7 & Bird & Continuous \\
Hopea dryobalonoides & Dipterocarpaceae & 61.5 & Wind & Not known \\
Mastixia trichotoma & Cornaceae & 40.1 & Animal? & Not known \\
Swintonia schwenkii & Anacardiaceae & 132.0 & Wind & Continuous \\
\hline
\end{tabular}


remnant old-growth forest. We assume that the effect of omitting outside mother trees is not large.

Parameters $a$ and $r$ were determined by the maximum likelihood method assuming Poisson error function. The log likelihood was:

$$
\ln L=\sum_{j=1}^{m} \ln \left[\frac{e^{-\lambda_{j}} \lambda_{j}^{z_{j}}}{z_{j} !}\right]
$$

$\lambda_{j}$ is the expected number of saplings in the $j$-th subplot as

$\lambda_{j}=A_{j} D_{j}$

where, $A_{j}$ is area $\left(\mathrm{m}^{2}\right)$ of the $j$-th subplot, $z_{j}$ is actual number of saplings $(0-100 \mathrm{~cm}$ in height) in 1989 in the $j$-th subplot, and $m$ is the number of subplots. Tree diameter in 1989 was used for $B_{i} \cdot \log L$ was maximized by Solver of Microsoft Excel. Significance of the model was tested by the likelihood ratio test using the null model of uniform sapling density.

Topographic environments may have an affect on the success of plant at germination and establishment stages. To detect such effects, the correlation between residuals $\left(z_{j}-\lambda_{j}\right)$ of the dispersal model and topographic environments (slope inclination, laplacian representing concavity, and logaritmic specific catchment area representing wetness) were calculated.

\section{Analysis of survivorship}

Survivorships from 1989 to 1998 of seven species were analyzed. Slope inclination, laplacian, and logaritmic specific catchment area were considered as topographic environments, and juvenile density of the same species in subplots in 1989, the total basal area (BA) of the same species in subplots in 1996, and the total BA of all species in subplots in 1996 were considered as biological environments. Logistic regression with a stepwise variable selection procedure (SPSS 12.0J) was used to detect significant environmental factors on survival. Survival (value=1) or death (value=0) of juveniles in 1998 was assumed as a dependent variable, and topographical and biological environmental variables as independent variables.

\section{RESULTS}

Juvenile and adult tree distribution of seven tree species is shown in Fig. 1. Trees distributed almost evenly in Cleistanthus glandulosus, Swintonia schwenkii and Grewia florida, whereas aggregated in Hopea dryobalanoides and Gonystylus forbesii. Calophyllum soulattri had few adults and many juveniles.

The number of juveniles of seven tree species decreased during the research period (Fig. 2), representing lesser recruitment than mortality. Calophyllum soulattri had the highest sapling density (0-100 cm in height) throughout the research period, whereas saplings of Gonystylus forbesii and Grewia florida were not abundant. The most abundant species in young trees (101-1000 cm in height) was different from those of saplings. Gonystylus forbesii and Cleistanthus glandulosus were abundant species, and Grewia florida and Mastixia trichotoma had a few young trees.

\section{Dispersal kernel}

Dispersal kernels were significant for three species having large number of juveniles such as Calophyllum soulattri, Gonystylus forbesii and Mastixia trichotoma (Table $2, \mathrm{P}<0.001$ ). In contrary these were not significant in Grewia florida, Hopea dryobalanoides and Swintonia schwenkii (Table 2, P > 0.1). Estimation of sapling density was successful for Calophyllum soulattri, however, juvenile densities in Gonystylus forbesii and Mastixia trichotoma were lower than expected in some subplots having high expected sapling density (Fig. 3). No significant correlation was found $(\mathrm{P}>0.05)$ between residuals (actual sapling number in subplot - predicted number) and environmental factors (slope, laplacian, and log catchment area), except for slightly more juveniles than expected in subplots of large catchment area in Mastixia trichotoma $(\mathrm{P}<0.05)$.

\section{Survivorship}

The survivorship rate of saplings (0-100 cm in height) over nine years (1989-1998) was high in Swintonia schwenkii, Gonystylus forbesii and Mastixia trichotoma (62.3\%, 60.7\% and 52.2\% respectively) (Table 3). Grewia florida and Hopea dryobalanoides had low survivorship rates (35.7\% and $33.1 \%$, respectively). The survivorship rates of young trees $(101-1000 \mathrm{~cm}$ in height) over nine years were generally higher than those of saplings except for Swintonia schwenkii (Table 4). Survivorship rates were high in Hopea dryobalanoides and Gonystylus forbesii (76.4\% and $65.6 \%$ respectively). Grewia florida had a low survivorship rate of $47.1 \%$.

In saplings, conspecific plants caused negative effects in four species, whereas topography showed less importance than conspecific plants (Table 3). The high density of conspecific saplings reduced the survival rate in Calophyllum soulattri and Hopea dryobalanoides, and large conspecific basal areas reduced the survival rate in Cleistanthus glandulosus and Swintonia schwenkii (Fig. 4). Topography was significant in Mastixia trichotoma, 

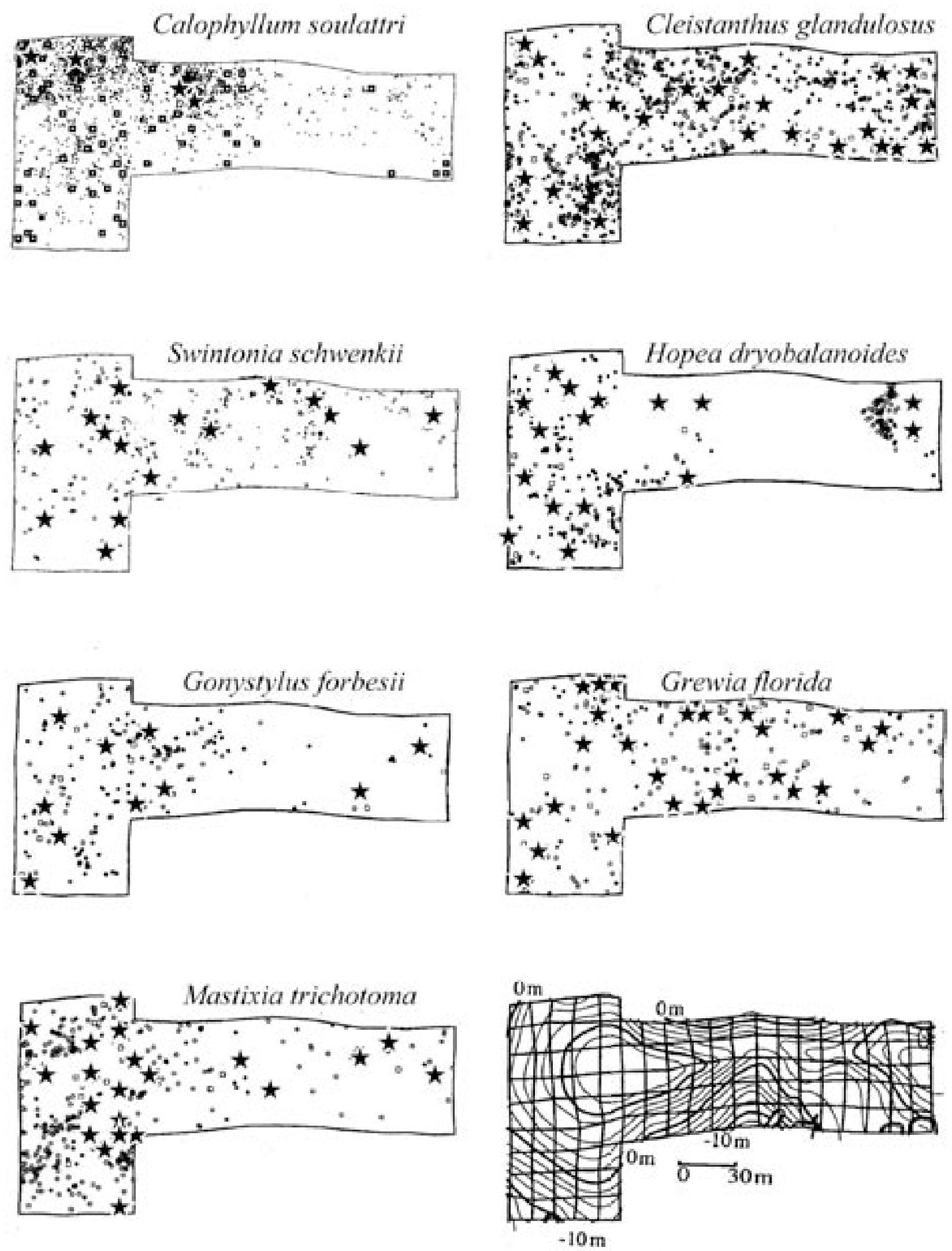

Fig. 1. Distribution map of juveniles and adult trees, and topography with $2 \mathrm{~m}$ contour. Cited and modified from Suzuki and Kohyama, 1991; Mukhtar et al., 1992; Kohyama et al., 1994.

saplings < $100 \mathrm{~cm}$; young trees $101-1000 \mathrm{~cm}$; $\square>1001 \mathrm{~cm}$ in high and $\mathrm{DBH}<9 \mathrm{~cm}$; $\star$ tree (DBH $>9 \mathrm{~cm})$ 

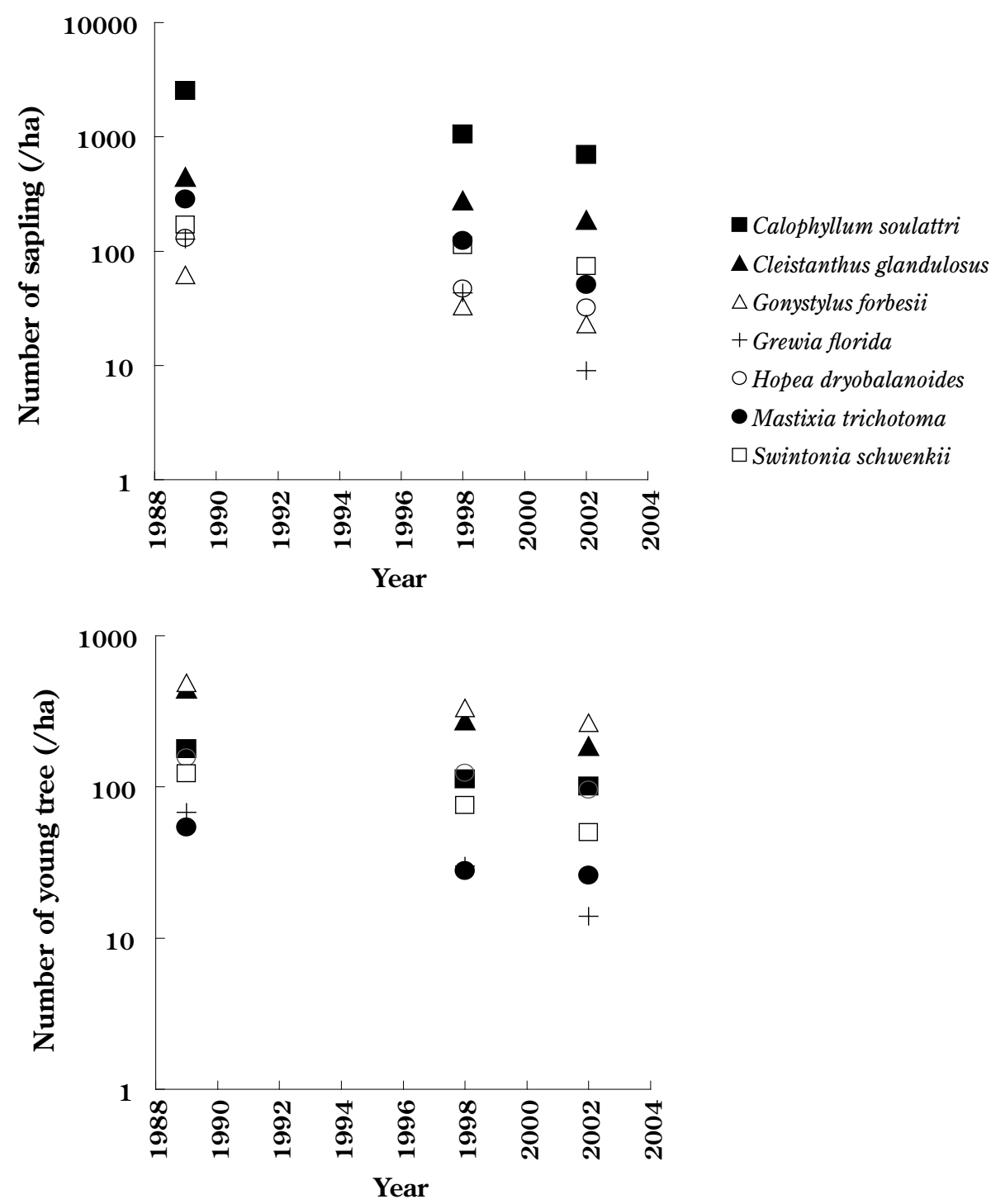

Fig. 2. Number of saplings and young trees in the research period. Note that the numbers in 1998 and 2002 include new recruits, and the graph is not survivorship curve.

Table 2. Dispersal kernels for saplings (height $0-100 \mathrm{~cm}$ ). $B$ is basal area of the mother tree in $\mathbf{m}^{2}$.

\begin{tabular}{lcc}
\hline \multicolumn{1}{c}{ Species } & $\begin{array}{c}\text { Sapling density }\left(\mathrm{m}^{-2}\right) \text { from a single } \\
\text { mother tree standing } x \text { m distant }\end{array}$ & Significance \\
\hline Calophyllum soulattri. & $3.78 B e^{-0.0733 x}$ & $\mathrm{P}<0.001$ \\
Cleistanthus glandulosus & $0.443 B e^{-0.00812 x}$ & $\mathrm{P}<0.1$ \\
Gonystylus forbesii & $0.430 B e^{-0.0533 x}$ & $\mathrm{P}<0.001$ \\
Grewia florida & - & $\mathrm{ns}$ \\
Hopea dryobalonoides & - & $\mathrm{ns}$ \\
Mastixia trichotoma & $0.175 B e^{-0.0357 x}$ & $\mathrm{P}<0.001$ \\
Swintonia schwenkii & - & $\mathrm{ns}$ \\
\hline
\end{tabular}

ns: not significant 

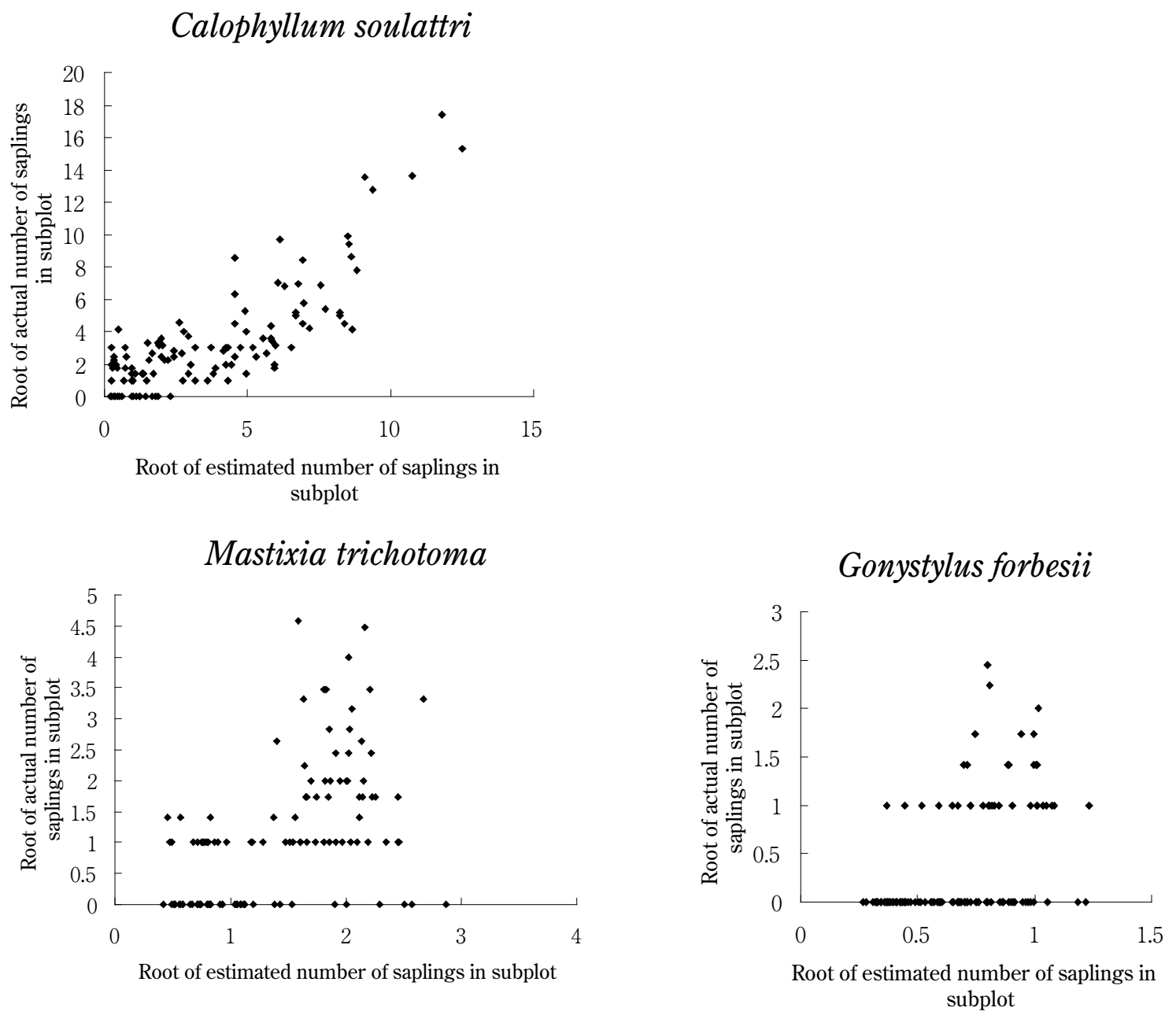

Fig. 3. Number of actual and estimated sapling numbers in subplots. Estimated number was $\lambda_{j}$ in the equation 2.

and was the second or third significant variable in Calophyllum soulattri.

In young trees, conspecific plants also caused negative effects in three species, and topography generally showed less importance than conspecific plants (Table 4). The effect of conspecific young tree density was significant in Mastixia trichotoma, and conspecific basal area was significant in Calophyllum soulattri and Swintonia schwenkii. Another significant variable was total basal area in Cleistanthus glandulosus. Topography was significant only for Cleistanthus glandulosus as the second variable.

\section{DISCUSSION}

Seed limitation caused by the dispersal process was detected in three species (Calophyllum soulattri, Gonystylus forbesii and Mastixia trichotoma) among seven examined and neighboring conspecific plants caused sapling mortality in four species. Aggregated spatial patterns of saplings will be produced by the seed dispersal process, but density dependent mortality decreases the aggregated spatial heterogeneity. Relatively uniform tree distribution will be formed through these processes. It might be one reason for sparse distribution of many tree species in tropical rain forests.

Since reproduction is rarely observed due to gregarious reproduction of this region (Inoue \& Nakamura, 1990), we might be able to observe only limited stages of these processes in a given snapshot survey. Calophyllum soulattri in 1989 might be close to the first stage just after the mass reproduction. Mastixia trichotoma in 1989 might be in the following stage after the mortality process. Species with continuous reproduction (Swintonia schwenkii and Grewia florida) may not form quite an aggregated sapling distribution, 
Table 3. Results of survival analysis for saplings $(0-100 \mathrm{~cm}$ in height). Environmental variables used in logistic regression with stepwise variable selection procedure were basal area of all species, basal area of the own species, sapling density of the own species, slope inclination, log catchment area, and laplacian of each subplot. Laplacian represents concavity of ground relief and was calculated as second deliberative.

\begin{tabular}{|c|c|c|c|c|c|}
\hline Species & $\begin{array}{c}\text { Number of } \\
\text { saplings in } \\
1989 \\
\text { (survival } \\
\text { rates for nine } \\
\text { years) }\end{array}$ & $\begin{array}{c}\text { One variable } \\
\text { model }\end{array}$ & $\begin{array}{l}\text { Two variables } \\
\text { model }\end{array}$ & $\begin{array}{l}\text { Three variables } \\
\text { model }\end{array}$ & $\begin{array}{c}\text { Significant } \\
\text { variables in single } \\
\text { variable analysis }\end{array}$ \\
\hline Calophyllum soulattri & $\begin{array}{c}2600 \\
(42.20 \%)\end{array}$ & -Sapling density** & $\begin{array}{l}\text {-Sapling density }{ }^{* *} \\
+ \text { Slope }^{* *}\end{array}$ & $\begin{array}{l}\text {-Sapling density }{ }^{* *} \\
+ \text { +Slope } \\
+ \text { Laplacian** }\end{array}$ & $\begin{array}{l}\text {-Sapling density** } \\
\text {-Own BA** } \\
\text {-Total BA* } \\
\text { +Slope** } \\
\text { +Laplacian** }\end{array}$ \\
\hline Cleistanthus glandulosus & $\begin{array}{c}442 \\
(48.9 \%)\end{array}$ & $-O w n \mathrm{BA}^{* *}$ & ns & ns & $\begin{array}{l}\text {-Own BA** } \\
\text {-Slope }\end{array}$ \\
\hline Gonystylus forbesii & $\begin{array}{c}61 \\
(60.7 \%)\end{array}$ & ns & ns & ns & ns \\
\hline Grewia florida & $\begin{array}{c}126 \\
(35.7 \%)\end{array}$ & ns & ns & ns & ns \\
\hline Hopea dryobalonoides & $\begin{array}{c}127 \\
(33.1 \%)\end{array}$ & -Sapling density** & ns & ns & $\begin{array}{l}\text {-Sapling density** } \\
\text { +Catchment area* }\end{array}$ \\
\hline Mastixia trichotoma & $\begin{array}{c}278 \\
(52.2 \%)\end{array}$ & -Laplacian** & ns & ns & $\begin{array}{l}\text {-Laplacian** } \\
\text {-Catchment area** }\end{array}$ \\
\hline Swintonia schwenkii & $\begin{array}{c}168 \\
(62.3 \%)\end{array}$ & -Own BA** & ns & ns & $\begin{array}{l}\text {-Own } \mathrm{BA}^{* *} \\
\text {-Total BA* }\end{array}$ \\
\hline
\end{tabular}

${ }^{* *} \mathrm{P}<0.01,{ }^{*} \mathrm{P}<0.05$, ns: not significant
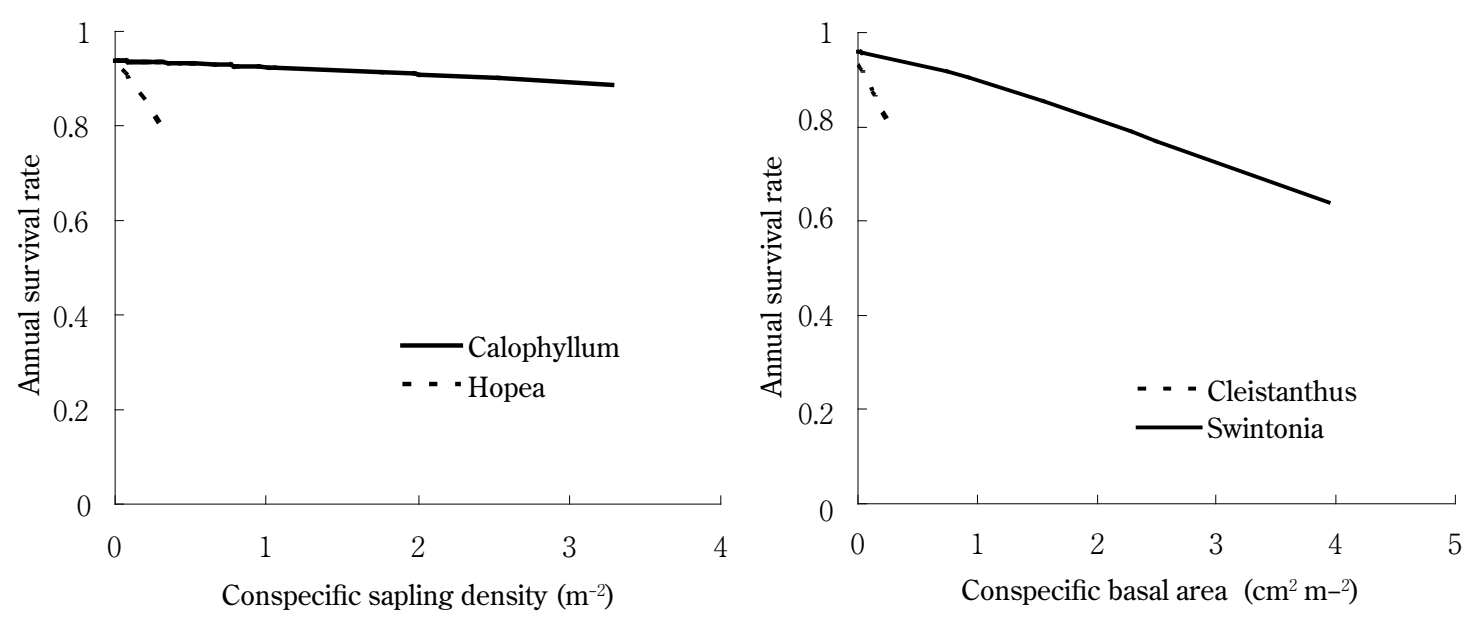

Fig. 4. Effect of sapling density and basal area (BA) of the own species on survivorship of saplings (0-100 $\mathrm{cm}$ in height). Estimated curves are shown.

due to the larger contribution of old saplings than in the case of having many one-year-old seedlings in species with mass reproduction.

Density dependent mortality has been reported in many cases. Tomita et al. (2002) found intensive seed predation in high seed density sites of beech. The mechanism of density dependent mortality for species studied in this study is not known (Janzen, 1970).

Seed dispersal kernel could not be detected in about half of the studied species. We used saplings of 0-100 cm 
Table 4. Results of survival analysis for young trees (101-1000 cm in height). Environmental variables used in logistic regression with stepwise variable selection procedure were basal area of all species, basal area of the own species, sapling density of the own species, slope inclination, log catchment area, and laplacian of each subplot.

\begin{tabular}{|c|c|c|c|c|c|}
\hline Species & $\begin{array}{l}\text { Number of } \\
\text { young trees } \\
\text { in } 1989 \\
\text { (survival } \\
\text { rates for nine } \\
\text { years) }\end{array}$ & One variable model & $\begin{array}{l}\text { Two variables } \\
\text { model }\end{array}$ & $\begin{array}{c}\text { Three } \\
\text { variables } \\
\text { model }\end{array}$ & $\begin{array}{c}\text { Significant variables } \\
\text { in single variable } \\
\text { analysis }\end{array}$ \\
\hline Calophyllum soulattri. & $\begin{array}{c}180 \\
(63.9 \%)\end{array}$ & -Own BA** & ns & ns & $\begin{array}{l}\text {-Young tree density* } \\
\text {-Own BA** }\end{array}$ \\
\hline Cleistanthus glandulosus & $\begin{array}{c}490 \\
(60.8 \%)\end{array}$ & + Total BA* & $\begin{array}{l}\text { +Total BA* } \\
+ \text { +Catchment area* }\end{array}$ & ns & $\begin{array}{l}\text { +Total BA* } \\
+ \text { +Catchment area* }\end{array}$ \\
\hline Gonystylus forbesii & $\begin{array}{c}122 \\
(65.6 \%)\end{array}$ & ns & ns & ns & ns \\
\hline Grewia florida & $\begin{array}{c}68 \\
(47.1 \%)\end{array}$ & ns & ns & ns & ns \\
\hline Hopea dryobalonoides & $\begin{array}{c}161 \\
(76.4 \%)\end{array}$ & ns & ns & ns & ns \\
\hline Mastixia trichotoma & $\begin{array}{c}47 \\
(53.2 \%)\end{array}$ & -Young tree density* & ns & ns & -Young tree density* \\
\hline Swintonia schwenkii & $\begin{array}{c}125 \\
(56.8 \%)\end{array}$ & $-\mathrm{Own} \mathrm{BA}^{*}$ & ns & ns & $-\mathrm{Own} \mathrm{BA}^{*}$ \\
\hline
\end{tabular}

${ }^{* *} \mathrm{P}<0.01,{ }^{*} \mathrm{P}<0.05$, ns: not significant

height in this research. However, clearer dispersal kernel may be obtained using seeds or one-year-old seedlings. Other reasons such as the relatively longer dispersal distance compared to distance among mother trees, nonsynchronous reproduction of large trees, significant number of mother trees outside the plot, and the death of large mother trees just before the research period might cause the failure of dispersal kernel estimation. While we considered mother trees only within the plot, the half decrease distance of Calophyllum soulattri sapling density was $9.5 \mathrm{~m}$ (Table 2), and the effect caused by mother trees outside the plot should be limited.

Although a model simultaneously including both dispersal and survival processes is possible, we could not determine optimum parameters as inverse problems, because there were many possible parameter sets having similar likelihoods. Thus we analyzed both processes separately.

Although soil condition may have an effect on tree distribution (Masunaga et al. 1997; Kubota et al. 2000; Hermansah et al. 2002; Palmiotto et al. 2004), topography was a less important environmental factor for sapling survival compared to the negative effects by conspecific plants in this study. Soil condition had effects on sapling survival in cases of large environmental difference. Russo et al. (2005) found that Hopea dryobalanoides had significantly higher survival rates in udult soil than in low-fertile humult soil in gap areas of Lambir National Park, Sarawak, Malaysia. Whereas Swintonia schwenkii had no significant differences in survival rates between soils in their research site. Our research site was limited to a ridge area of small spatial scale (Fig. 1), and a narrow environmental range might be a reason for the small effect of topography. Studies in larger topographic gradients is required to clarify the importance of topography on sapling survival and to evaluate the importance of the sapling stage on the development of spatial distribution patterns of adult trees. In otherwords, the pattern of species dispersion is mainly regulated by intraspecific density dependence at a local $(<1 \mathrm{ha})$ spatial scale.

ACKNOWLEDGEMENTS We would like to express our appreciation to Prof. Mitsuru Hotta of Kagoshima Prefecture College and Prof. Kazuhiko Ogino of The University of Shiga Prefecture for their initiation and valuable advices for this research. We give special thanks to Prof. Tsuyoshi Yoneda of Kagoshima University for his comments on the early manuscript. This study is based on a long-term observation, and the late Prof. Syunzo Kawamura of Kyoto University had supported this study throughout the period under the Sumatra Nature 
Study (SNS) Project and the Field Biology Research and Training (FBRT) Project in Padang. We also give our thanks to Prof. Eizi Suzuki and Prof. Takeshi Kohyama for their permission to use their initial data. We are grateful to Prof Marlis Rahman, Prof Syahbuddin and students of the Department of Biology, Andalas University, Indonesia, for their advice and help in the field. Thanks are also due to Mr. William L. Ding-Everson, Programme Assistant of CITYNET, The Regional Network of Local Authorities for the Management of Human Settlements, Yokohama, Japan, who kindly corrected the English of this manuscript. The first author (Erizal Mukhtar) would like to thank TPSDP (Technological and Professional Skills Development Sector Project, ADB Loan No. 1792-INO) for financial support for his Visiting Research Fellowship at Yokohama National University, Japan.

\section{REFERENCES}

Clark, J.S., Silman, M., Kern, R., Macklin, E. \& Lambers, J.H. 1999. Seed dispersal near and far : Patterns across temperate and tropical forests. Ecology, 80: 1475-1494.

Greene, D.F., Canham, C.D., Coates, K.D. \& Lepage, P.T. 2004. An evaluation of alternative dispersal functions for trees. Journal of Ecology, 92: 758-766.

Hermansah, Masunaga, T., Wakatsuki, T. \& Alfizar. 2002. Micro spatial distribution pattern of litterfall and nutrient flux in relation to soil chemical properties in a super wet tropical rain forest plot, West Sumatra, Indonesia. Tropics, 12: 131-146.

Inoue, T. \& K. Nakamura. 1990. Physical and biological background for insect studies in Sumatra. In: Natural history of social wasps and bees in equatorial Sumatra (eds. Sakagami, S., Ohgushi, R. \& Roubik, D.), pp. 1-11. Hokkaido University Press, Sapporo, Japan.

Janzen, D.H. 1970. Herbivores and the number of tree species in tropical forests. American Naturalist, 104: $501-527$.

Kohyama, T., Hotta, M., Ogino, K., Syahbuddin. \& Mukhtar, E. 1989. Structure and dynamics of forest stands in G. Gadut, West Sumatra. In: Diversity and plant animal interaction in equatorial rain forests (ed. Hotta, M.), pp. 33-47. Occasional papers of the Kagoshima University Research Center for South Pacific 16.

Kohyama, T., Suzuki, E. \& Hotta, M. 1994. Spatial distribution pattern of representative tree species in a foothill rain forest in West Sumatra. Tropics, 4:
$1-15$.

Koike, F. 2005. Minna de GIS. URL:www13.0cn.ne.jp/ minnagis/ (In Japanese)

Koike F. \& Syahbuddin. 1993. Canopy structure of a tropical rain forest and the nature of an unstratified upper layer. Functional Ecology, 7: 230-235.

Komuro, T. \& Koike, F. 2005. Colonization by woody plants in fragmented habitats of a suburban landscape. Ecological Applications, 15: 662-673.

Kubota, D., Masunaga, T., Hermansyah., Hotta, M. \& Wakatsuki, T. 2000. Soil quality characterization in relation to tree species diversity in tropical rain forest, West Sumatra, Indonesia. I. Comparison of two 1-ha plots. Tropics, 9: 133-145.

Masunaga, T., Kubota, D., Hotta, M. \& Wakatsuki, T. 1997. The nutritional characteristics of mineral elements of tree species of tropical rain forest, West Sumatra, Indonesia. Soil Science and Plant Nutrition, 43: 405-418.

Mukhtar, E., Suzuki, E., Kohyama, T. \& Rahman, M. 1992. Regeneration process of a climax species Calophyllum cf. soulattri in tropical rain forest of West Sumatra. Tropics, 2: 1-12.

Mukhtar, E., Yoneda, T., Zalfiati. \& Rahman, M. 1998. Regeneration process of a climax species Calophyllum cf. soulattri in tropical rain forest of West Sumatra: Population Dynamics of a Cohort from Mast Fruiting in 1981. Tropics, 7: 183-194.

Nathan, R., Perry, G., Cronin, J.T., Strand, A.F. \& Cain, M.J. 2003. Methods for estimating long-distance dispersal. Oikos, 103: 261-273.

Nathan, R. \& Casagrand, R. 2004. A simple mechanistic model of seed dispersal, predation and plant establishment: Janzen-Connell and beyond. Journal of Ecology, 92: 733-746.

Ogino, K., Hotta, M., Tamin, R. \& Yoneda, T. 1984. Forest ecology of G. Gadut area. In: Forest ecology and flora of G. Gadut West Sumatra (ed. Hotta, M.), pp. 15-37. Sumatra Nature Study (Botany), Kyoto, Japan.

Ohtani, S \& Koike, F. 2005. Implication of the $19^{\text {th }}$ landscape patterns for the recovery of Fagus crenata forests. Applied Vegetation Science, 8: 125-132.

Palmiotto, P.A., Davies, S.J., Vogt, K.A., Ashton, M.A., Vogt, D.J. \& Ashton, P.S. 2004. Soil-related habitat specialization in dipterocarp rain forest tree species in Borneo. Journal of Ecology, 92: 609-623.

Ribbens, E., Silander, J.A. \& Pacara, S.W. 1994. Seedling recruitment in forests: calibrating models to predict patterns of tree seedling dispersion. Ecology, 75: 
1794-1806.

Russo, S.E., Davies, S.J., King, D.A. \& Tan, S. 2005. Soilrelated performance variation and distributions of tree species in a Bornean rain forest. Journal of Ecology, 93: 879-889.

Skarpaas, O., Shea, K. \& Bullock, J.M. 2005. Optimizing dispersal study design by Monte Carlo simulation. Journal of Applied Ecology, 42: 731-739.

Suzuki, E. \& Kohyama, T. 1991. Spatial distributions of wind-dispersed fruits and trees of Swintonia schwenkii in a tropical forest of West Sumatra. Tropics, 1: 131-142.

Tomita, M., Hirabuki, Y. \& Seiwa, K. 2002. Post-dispersal changes in the spatial distribution of Fagus crenata seeds. Ecology, 83: 1560-1565.

Trakhtenbrot, A., Nathan, R., Perry, G. \& Richarson, D.M.. 2005. The important of long-distance dispersal in biodiversity conservation. Diversity and Distribution, 11: 173-181.

Yoneda, T., Tamin, R. \& Ogino, K. 1990. Dynamics of aboveground big woody organs in a foothill dipterocarp forest, West Sumatra, Indonesia. Ecological Research, 5: 111-130.

Yoneda, T., Ogino, K., Kohyama, T., Tamin, R., Syahbuddin \& Rahman, M. 1994. Horizontal variance of stand structure and productivity in a tropical foothill rain forest, West Sumatra, Indonesia. Tropics, 4: 17-33.

Yoneda, T., Mizunaga, H., Nishimura, S., Fujii, S., Mukhtar, E., Hotta, M. \& Ogino, K. 2006. Impacts of recent dry weather on a tropical rain forest in Sumatra with special reference to stand dynamics during the last two decades. Tropics, 15: 189-200.

Received $22^{\text {nd }}$ Apr. 2006

Accepted $10^{\text {th }}$ Aug. 2006 